\title{
Sustainable Tourism Approach in Trowulan Heritage Destination - Mojokerto, East Java
}

\author{
$1^{\text {st }}$ Diena Mutiara Lemy ${ }^{1}, 2^{\text {nd }}$ Elang Kusumo ${ }^{2}$ \\ \{diena.lemy@uph.edu ${ }^{1}$, elangkusumo1551@gmail.com ${ }^{2}$ \}
}

\author{
Universitas Pelita Harapan, School of Hospitality and Tourism, \\ UPH Tower D 3rd floor Lippo Village Karawaci Tangerang Indonesia ${ }^{1,2}$
}

\begin{abstract}
Trowulan as one of cultural heritage tourism sites in Indonesia has a strategic role in building the national identity, considering that Trowulan is the center of Majapahit, a large kingdom around the 13th century whose territory covered the territory of the present Indonesia to the Malay peninsula. The Trowulan site is currently under the management of the East Java Cultural Heritage Preservation Center (BPCB), Directorate General of Culture, Ministry of Education and Culture. The focus of BPCB in managing this site is Rescue, Secure, Maintenance and Development of cultural heritage. Some problems related to the discovery of cultural heritage objects and interest conflicts of local people in earning a living in the land area become critical issues that should be addressed. Based on the description above, this paper reviews the Sustainable Tourism approach to help overcome the problems in Trowulan.
\end{abstract}

Keywords: sustainable tourism, Trowulan, cultural heritage tourism, Majapahit kingdom

\section{Introduction}

Majapahit Kingdom (Majapahit) is one of powerful kingdoms in Indonesia. Founded by Raden Wijaya in 1293 AD, Majapahit reached its peak in 1350 - 1389 under King Hayam Wuruk [1]. The center of Majapahit, based on the results of research and archaeological remains, is the Trowulan site. Trowulan Site is a very important historical area. The Trowulan site is located $70 \mathrm{~km}$ southwest of Surabaya in the Trowulan District area (Mojokerto Regency, East Java). In an area of $9 \times 11 \mathrm{~km}$, brick buildings in the form of temples, arches, ponds and waterways can be found on the ground or underground, which indicate a city that can be considered advanced for that period. The discovery of the Trowulan site began from a study carried out by Wardenaar in 1815 to observe the archaeological remains in the Mojokerto area.

Despite of its great potential, the Trowulan site has various problems. The problems are related to the high population density in this area, causing the local residents ' need for land to increase [1], In some cases, the discovery of some of the cultural heritage objects, people's behavior, and people's livelihood make the damages to the site get worse [2]

Another problem arise from the time needed for categorizing the objects by Cultural Heritage Preservation Center (BPCB). The process might need some time and often take too 
long in the waiting period. Thus, landowners cannot make a living from their own land. As a result, landowners will feel disadvantaged.

The problem became more complicated when the Decree of the Minister of Education and Culture of the Republic of Indonesia No. 260 / M / 2013 was issued. This decree declared Trowulan Geographical Space Unit as a national Cultural Heritage Area covering $92.6 \mathrm{~km} 2$ are, consisting of Mojokerto and Jombang Districts, and also Trowulan, Sooko, Mojoagung, and Mojowarno, and 49 villages. This resulted in some consequences; one of which is the prohibition of acts of destruction, stealing, transferring and or separating cultural heritage in the region. The declared status of Trowulan site as a National Cultural Heritage Area triggered the conflict between the government and local community because the bricks industry run by the local community used soil obtained from the area, threatening cultural heritage still buried in the ground. On the other hand, the local community feels unsecure because the status of Trowulan site as a National Cultural Heritage Area might threathen their livelihood.

It is clear that the situation in Trowulan needs to be addressed since the conflict between local residents and the government might lead to a more serious situation. The solutions of the problems must be win-win solutions to all stakeholders. Since Trowulan has a great potential as a cultural heritage destination, this paper explores the opportunity of applying Sustainable Tourism Concept in this area. Based on the conceptual definition of UNWTO (2004), sustainable tourism development emphasizes environmental, socio-cultural and economic balance by:

1. making optimal use of natural resources which are key elements in the development of tourism, maintain the necessary ecological processes, and conserve natural resources and biodiversity;

2. Respecting the socio-cultural values of the local community, preserving cultural heritage and traditional values, and contributing to the creation of mutual understanding and tolerance among cultures

3. Ensuring long-term economic operations, providing social economic benefits to all stakeholders equally, including employment and stable employment opportunities and social services for local communities, as well as contributing to poverty alleviation [3]

The concept of sustainable tourism is chosen because of the following reasons: 1) Trowulan as cultural heritage sites has a potential value to be developed as tourism destination; 2) due to the high density of population in the area, a solution highly considering the community as the main stakeholder is needed. Sustainable tourism pays serious attention to the community; 3) the principle of Sustainable Tourism adopted from The Global Sustainable Tourism Council (GSTC) has considered the balanced role and benefit of Governance, Economic benefits, Cultural Preservation benefits and Environmental preservation benefit.

\section{Literature Review}

\subsection{Trowulan Heritage Site}

As stated in the Law of the Republic of Indonesia Number 11/2010 concerning Cultural Heritage, cultural heritage is the wealth of national culture as a manifestation of thoughts and behaviors of human life important for understanding and developing history, science, and culture in community life, nationhood, and the state so that it needs to be preserved and 
managed appropriately through protection, development and utilization efforts for advancing national culture for the greatest prosperity of the people. The Trowulan site has an important historical value for Indonesia, because it represents the greatness of Majapahit Kingdom. The Trowulan site in Trowulan District is an area consisting of 16 villages. It is known as the capital city of Majapahit; many relics of the Majapahit Kingdom can be found in the area of 39.20 square kilometers [4].

Based on the material, artifacts found at the Trowulan site can be classified as follows:

a. Terracotta artifacts (made of pottery clay), which consist of: 1) human sculptures/statues (various races such as Chinese, Indian, Arabic); 2) household appliances such as water bottles, water tanks, piggy banks; 3) production equipment, including: sculpture, kowi (metal molds, made of clay); and 4) building and house elements such as miniature houses, pillars, roof tiles, tops, air pipes and jaladwara.

b. Ceramic artifacts (made from ceramics) such as plates, glasses, vases, glasses made locally or from abroad.

c. Metal artifacts (made of metal) which include: coins made locally and from abroad, ceremonial tools such as bells, mirrors, zodiac bread makers, incense burning.

d. Stone artifacts (such as from andesite or tufa) such as reliefs, statues, and tablets [5]

To successfully operate heritage tourism destination requires hard work and focus. Conflicts related to the preservation of inheritance, tourist visits, and residence of residents require special attention [6]. One of the conflicts involved the red brick industry dominated by the local community because it was one of the local population livelihoods [7].

\subsection{Tourism}

Tourism is a social, cultural and economic phenomenon which entails the movement of people in a country or place outside their home/environment for personal or business purposes. They are called visitors (tourists or tourists; occupants or non-residents) and it has to do with their activities, and the implications of tourism expenditure [8].

Mousavi, Doratli, Mousavi, \& Moradiahari (2016) describe that there are two definitions of tourism ; 'conceptual' tourism, related to the core meaning of tourism, and 'technical' definition of tourism, emphasizing the tourism values evaluation and measurement which are different in various countries. Conceptual definition is the temporary short term movement of people for all purposes to destination outside their home where they normally live and work, and activities during their stay at the destinations, and also for a day visits. Technical definition refers to people's activities during their journey of travel and stay in a place outside their usual place for a period of less than a year for leisure, work or other purposes [9].

There are four tourism basic components, known as 4 As: Attraction, Accessibility, Amenities, and Ancillary [10]: a. attraction which refers to the object of tourism which includes the uniqueness and attraction of nature, culture and artificial; b. accessibility which includes the ease of transportation facilities and systems; c. amenities that include supporting and supporting tourism facilities; and $d$. ancillary public facilities that support tourism activities [11]

\subsection{Sustainable Tourism}

Tourism has a strategic role in achieving the Sustainable Development Goals (SDGs) set by the United Nation. There are 17 objectives of SD tobe achieved until 2030. The UNWTO 
underlines three objectives in the SDGs which are the role of sustainable tourism; 8th (Decent work and Economic growth), sustainable tourism promotes an inclusive economy and access to decent work for all people, 12th (responsible consumption and production) which requires the development and implementation of instruments to monitor the impact of sustainable development on sustainable tourism, 14th (Life below water) emphasizes conservation and conservation of marine resources considering that marine tourism is the largest tourism segment.

UNWTO established 2017 as the Year of Tourism for Sustainable Development. This encourages every element (stake holders) in tourism industry to manage tourism responsibly and sustainably and to optimize social and economic benefits by minimizing negative impacts on local communities and environment. Policy makers, tourism industry services provider, and travellers contribute to implementing sustainable tourism. Sustainable tourism development emphasizes environmental, socio-cultural and economic balance by:

a. Using natural resources optimally, which are key elements in the development of tourism, maintain the necessary ecological processes, and conserve natural resources and biodiversity

b. Respecting the socio-cultural values of the local community, preserving cultural heritage and traditional values, and contributing to the creation of mutual understanding and tolerance among cultures

c. Ensuring long-term economic operations, providing social economic benefits to all stakeholders equally, including employment and stable employment opportunities and social services for local communities, as well as contributing to poverty alleviation [3].

The Global Sustainable Tourism Council (GSTC) establishes and manages global sustainable standards, known as the GSTC Criteria. Indonesia adapted and used these criteria for public policy makers and destination managers, and for hotels industry and tour operators. The Criteria become a guiding principle and minimum requirements that must be followed by businesses or tourism destinations to protect and conserve the world's natural and cultural resources, and ensure tourism optimilizing its potential as a tool for conservation and poverty alleviation [12]

The GSTC Criteria are the minimum requirements that must be met by any tourism management organization for implementing sustainability practices. To meet the definition of sustainable tourism, destinations must take an interdisciplinary, holistic and integrative approach which includes four main objectives: (i) demonstrating sustainable destination management, (ii) maximizing economic benefits for local communities and minimizing negative impacts, (iii) maximizing profits for community, visitors and culture while minimizing negative impacts, and (iv) maximizing environmental benefits and minimizing negative impacts [12]

\section{Methodology}

This preliminary research focuses on the possibility of applying sustainable tourism concept in Trowulan as a potential cultural heritage tourism site. Therefore, explorative qualitative method employed to obtain data on community awareness and support for the implementation of Sustainable Tourism.

The data collection method used interviews with the local community which was represented by the leader of the coordinator of Mandala Majapahit community, the local transport business and the local guide. The three interviewees were chosen because of their involvement in the heritage activities in Trowulan. The interview questions are: 1) What are the main problems 
of Trowulan; 2) What are their opinions about cultural heritage tourism in Trowulan; 3) What do they think about sustainable tourism concept (after the concept is being explained to them).

To support the primary data, secondary data were gathered from Central Bureau of Statistics and East Java Cultural Heritage Preservation Center (BPCB).

\section{Result and Discussion}

Trowulan site has a great potential to be developed as a tourism destination because of its valuable historical relics. However, until now, the focus of management in Trowulan has not included tourism. In terms of the number of visitors to Trowulan, the rate of tourist visits has been declining since 2016.

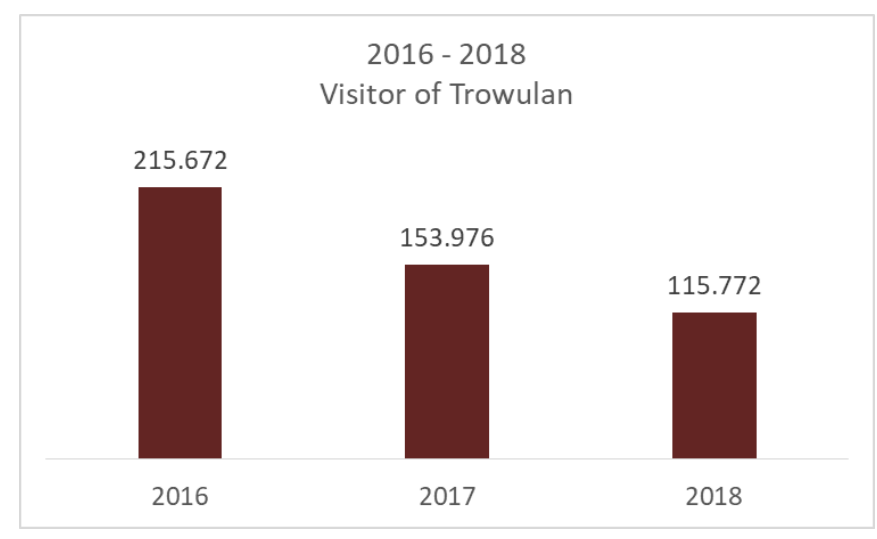

Fig. 1. Visitor of Trowulan 2016 - 2018. Source: BPCB 2019

Based on data from the interviews, the local community confirmed the existence of conflict with the government, as indicated by previous research. Below is the interview results:

Table 1. Interview Results.

\begin{tabular}{|c|c|}
\hline Questions & Example \\
\hline $\begin{array}{l}\text { 1. What are the main } \\
\text { problems of Trowulan }\end{array}$ & $\begin{array}{l}\text { - Gap between government and the local } \\
\text { community } \\
\text { - Lack of the involvement from the local } \\
\text { community in Trowulan development }\end{array}$ \\
\hline $\begin{array}{l}\text { 2. What are their opinions } \\
\text { about cultural heritage } \\
\text { tourism in Trowulan }\end{array}$ & $\begin{array}{ll}\text { - } & \text { Priceless heritage } \\
\text { - } & \text { High Potential for tourism } \\
\text { - } & \text { Need guidance and capacity building }\end{array}$ \\
\hline $\begin{array}{l}\text { 3. What do they think about } \\
\text { sustainable tourism } \\
\text { concept }\end{array}$ & $\begin{array}{ll}\text { - } & \text { Good concept } \\
\text { - Need to be guided to implement the concept } \\
\text { - Will involve the local community } \\
\text { - }\end{array}$ \\
\hline
\end{tabular}


The conflicts arise because there was a communication gap between the government and the local community. Often, members of the community feel that they were not involved in some government's program in Trowulan. One example is when the government of the regency built some homestays with Majapahit style. As a result, now many homestays are abandoned because both the government and the local communities do not know how to handle the homestays. In addition, potential conflicts of interest between the stakeholders still remain due to the livelihood of the local community and the law enforcement of discovering cultural heritage objects.

However, aside from the conflicts faced by the stakeholders, the local communities realize that Trowulan has a great potential as a cultural heritage tourism destination. They have a high expectation that one day their area will be developed in the corridor of tourism framework. One of their dreams is to form a Tourist Village (Desa Wisata) in Trowulan. Currently, they are Tourism Awareness Groups (Kelompok Sadar Wisata - Pokdarwis), working groups at the local community level. However, capacity building and assistance from the government is still needed to make them understand how to develop tourism in Trowulan.

After being explained about the concept of sustainable tourism, the interviewees showed a high interest on the concept, especially on the economic pillar. It is very common that economic benefits become the main attraction of any tourism development. Therefore, a proper mentoring and assistance to Trowulan local community in the framework of sustainable tourism might provide a solution to the long conflict in this site.

\section{Conclusion}

The results of this research show that Trowulan as a tourist destination should be managed based on the Sustainable Tourism Concept, which is focused on the benefits of economy, culture and environment preservation by implementing good management tourism. The conflicts between stakeholders can be eliminated by growing more understanding of managing the destination, especially by the understanding each other's role. Having a good understanding can be a resource to develop Trowulan as a sustainable tourism destination, which gives the best experience to visitors and at the same time provides economic benefits to the local community and helps the preservation of the heritage sites.

\section{References}

[1] A. Akbar, "Conservation and Management of Archaeological Sites Cultural Resource Management for a Majapahit Kingdom Site in Trowulan, East Java, Indonesia Cultural Resource Management for a Majapahit Kingdom Site in Trowulan , East Java , Indonesia," vol. 5033, no. December, 2015.

[2] D. R. Wijayanti, "Musnahnya Peninggalan Bersejarah di Tanah Sendiri : Kondisi Sosial Ekonomi dan Kultural Masyarakat Trowulan, Potensi atau Masalah ?," pp. 1$11,2017$.

[3] I. G. Ardika, Kepariwisataan Berkelanjutan: Rintis Jalan Lewat Komunitas. Jakarta: Penerbit Buku Kompas, 2018.

[4] W. S. Eka Sapta Kartika Putri, Antariksa, "Citra Kawasan Cagar Budaya Trowulan," no. June, 2017.

[5] Kementerian Pariwisata, "Trowulan - Former Capital City of Majapahit Kingdom," UNESCO World Heritage Centre, 2009. .

[6] Y. Li, C. Hunter, A. Hassan, and M. Rahman, "Journal of Cultural Heritage Management and Sustainable Development "Community involvement for sustainable 
heritage tourism: a conceptual model" J. Cult. Herit. Manag. Sustain. Dev. Iss, vol. 5, no. 3, pp. 248-262, 2015.

[7] S. Biantoro, "The Political Economy of Cultural Heritage in Trowulan," https://www.insideindonesia.org/, 2016.

[8] World Tourism Organization, "Understanding Tourism : Basic Glossary,” pp. 1-3, 2017.

[9] S. S. Mousavi, N. Doratli, S. N. Mousavi, and F. Moradiahari, "Defining Cultural Tourism," 2016.

[10] D. G. and S. W. Chris Cooper, John Fletcher, Alan Fyall, Title Tourism : Principles and Practice, Fourth. Harlow, England : Prentice Hall Financial Times, 2008.

[11] L. H. Khusnul Khotimah Wilopo, "Strategi Pengembangan Destinasi Pariwisata Budaya (Studi Kasus pada Kawasan Situs Trowulan sebagai Pariwisata Budaya Unggulan di Kabupaten Mojokerto," vol. 41, no. 1, p. 10, 2017.

[12] Gstcouncil, "Global Sustainable Tourism Council," 2019. 